
\title{
РОД ВАСНЕЦОВЫХ, СВЯЩЕННИКОВ И ВОИНОВ, СКВОЗЬ ПРИЗМУ ПРОЕКТА «ВАСНЕЦОВСКИЕ СИМВОЛЫ ВЕЧНОСТИ»
}

\section{ROD VASNETSOV, PRIESTS AND WARRIORS, THROUGH THE PRISM OF THE PROJECT «VASNETSOV SYMBOLS OF ETERNITY»}

\section{E. Shcherbakova}

Summary: The article is devoted to the revival, preservation and development of traditions bequeathed to the descendants of the famous Vasnetsov family through the implementation of the project "Vasnetsov Symbols of Eternity" in the Igrinsky district of the Udmurt Republic. Orthodox values have historically consolidated unity and statehood, but today there is a danger of losing spiritual ideals, which causes a vital need to revive and develop traditions of mercy and pride in one's Fatherland. To help solve problems, you need a spiritual core, which is the creative legacy of the Vasnetsovs - a spiritual testament to descendants - to preserve tradition. As a rule, our knowledge of the talented Vasnetsovs is limited only to knowledge of the works of brothers-artists: Viktor Mikhailovich and Apollinar Mikhailovich. But no less remarkable are other representatives of this glorious family who have left a noticeable mark in our history.

Keywords: Vasnetsov, Vasnetsov's symbols, Vasnetsov's clan, art, priestly clan, culture.
Щербакова Елена Николаевна

Преподаватель, Краснодарское высшее военное училище имени генерала армии С.М. Штеменко sherbakova120559elena@mail.ru

Аннотация: Статья посвящена возрождению, сохранению и развитию традиций, завещанных потомкам знаменитым родом Васнецовых, через реализацию проекта «Васнецовские символы вечности» в Игринском районе Удмуртской республики. Православные ценности исторически скрепляли единство и государственность, однако сегодня возникает опасность утраты духовных идеалов, что вызывает жизненно важную необходимость возрождать и развивать традиции милосердия, гордости за свое Отечество. Чтобы содействовать решению проблем, необходим духовный стержень, коим и является творческое наследие Васнецовых - духовное завещание потомкам - беречь традицию. Как правило, наши знания 0 талантливом роде Васнецовых ограничиваются лишь знанием творчества братьев-художников: Виктора Михайловича и Аполлинария Михайловича. Но не менее замечательны и другие представители этого славного рода, которые оставили заметный след в нашей истории.

Ключевые слова: Васнецов, Васнецовские символы, род Васнецовых, искусство, священнический род, культура.

вавший деревянную Спасскую церковь, приход которой окормляли священнослужители рода Васнецовых более трехсот лет [1].

Практически весь род был священническим, наделенным от природы художественными способностями. Были среди них архитекторы, принимавшие участие в строительстве сельских каменных храмов, подготовке «художественных чертежей».

По их эскизам сооружались каменные церковные ограды и металлические решетки к ним, торговые лавки для ярмарок и собственные дома. Художественное дарование священников Васнецовых проявилось в проведении отделочных работ, росписи стен храмов, устройстве иконостасов, написании живописных работ [1]. Были среди священников Васнецовых и те, кто со всем вятским народом защищали свое Отечество «до последней капли крови».

В год юбилея Бородинской битвы телевидение Вятки совместно с государственным архивом Кировской об- 
ласти рассказывали об участии вятичей в тех грозных и судьбоносных событиях, о том, как вятские солдаты спасли в Европе уникальные произведения архитектуры и искусства и как в рядах ополчения оказались представители славного рода Васнецовых.

Судьба бывших ополченцев сложилась по-разному. Кто-то вернулся к своему обычному ремеслу и крестьянским занятиям. Некоторые были зачислены в счет рекрутов и уже никогда домой не вернулись. Некоторые, вернувшись домой, пошли на повышение по службе, например, как Алексей Васнецов [4].

Участие представителей священнического рода Васнецовых в Первой мировой войне (1914-1918гг.) также выражалось не только в поддержке словом и сборе средств и вещей для фронта, молитвенном предстоянии, но и непосредственно на полях сражений. Так, в начале Первой мировой войны сын русского живописца Виктора Васнецова, Михаил (1884-1972), был призван на службу и назначен командиром 4 й роты 46-го запасного батальона для обучения солдат перед отправкой на фронт.

В преддверии празднования 75-ой годовщины Великой Победы советского народа над фашизмом необходимо отметить, что потомки доблестного рода Васнецовых, как и их предки, с первого до последнего дня воевали вместе со всем советским народом на фронтах Великой Отечественной войны (1941-1945гг.), принимали участие в народном ополчении, работали на заводах, приближая Великую Победу, как, например, внуки священнослужителя-просветителя, оставившего славную память на Игринской земле, Николая Федоровича Васнецова: Николай, Виктор, Василий.

Николай Алексеевич Кузнецов (1922-2008), старший внук, после окончания 1-го курса исторического факультета Кировского государственного педагогического института им. В.И. Ленина был призван в Красную армию. Перед самой Великой Отечественной войной он окончил Читинскую школу младших авиаспециалистов (6.19405.1941) и принимал участие в боевых действиях сначала на Юго-Западном фронте в качестве авиамеханика ближнебомбардировочного авиационного полка в обороне г. Киева, в составе 451-го штурмового авиационного полка - в боях в районе городов: Осташково, Селижарово Калининской области (5.1941-7.1042). Затем, после обучения в Воздушно-десантном училище им. Красной армии в г. Москве (7.1942-5.1943), воевал на Северо-Западном, 3-ем Украинском фронтах. С 1944-1945 гг. дивизия в составе 9 Воздушно-десантной армии (ВДА) участвовал в освобождении Венгрии и Австрии. Николай Алексеевич принимал участие в качестве начальника склада горючесмазочных материалов дивизии в разгроме 11 танковой немецкой дивизии под озером Балатон, во взятии городов Венгрии и Австрии (5.1943-8.1946). После окончания Великой Отечественной войны 9 ВДА ушла из Венгрии на территорию СССР и дислоцировалась в Московской области, на станции Фруктовая [1].

В августе 1946 года Николай Алексеевич был направлен на учебу в интендантское военно-морское училище г. Выборга (8.1946-10.1950), по окончании которого служил на Северном Флоте. Подполковник, имеет правительственные награды: два ордена «Красная Звезда», «Орден Отечественной войны 2-ой степени» и медали.

Виктор Алексеевич Кузнецов (1925-1991), средний внук, участвовал в народном ополчении.

Василий Алексеевич Кузнецов (1927-2007), младший внук, во время войны работал токарем на заводе. После войны, в 1946 году, поступил в авиационную школу г. Чирчик (Узбекистан), где готовили летчиков тяжелой авиации. По окончании училища служил в городах: Конотопе, Нежине, Пряну, Кингисеппе, Петрозаводске, Тбилиси, поселке Урелики. Майор, имеет государственные награды - медали, грамоты.

Наш современник, правнук Николая Федоровича Васнецова, Олег Васильевич Кузнецов (1957), полковник, доктор экономических наук, профессор, проректор Финансового университета при Правительстве Российской Федерации, председатель Фонда сохранения культурного наследия Васнецовых, общественный деятель и ученый [1].

Таким образом, представители славного рода Васнецовых, как и все духовенство, не только героически, оставаясь на своих местах, исполняли пастырский долг - молебны о победе русского воинства - одну их важных форм деятельности Русской Православной церкви в годы войны, но и совершали свой ратный подвиг.

Воин-защитник нашего Отечества потому и побеждал во всех войнах, что имел особый духовный стержень, был крепок духом, знал свои корни и культурные ценности. Окружающие нас символы искусства, культуры учат любить историю и культуру нашей Родины, так как являются частью отеческого наследия.

Реализованный в год празднования 170-ти летия великого русского художника Васнецова Виктора Михайловича проект «Васнецовские символы вечности», получивший грант международного конкурса «Правосланая инициатива - 2017-2018» по благословению Святейшего Патриарха Московского и всея Руси Кирилла, свидетельствует об уникальности такого культурного кода, как род 
Васнецовых на Игринской земле.

Данный проект выступил своеобразным катализатором духовного сплочения жителей Игринского района Удмуртской Республики, сыграл облагораживающую роль, направленную на осознание личностью своей принадлежности к великим традициям родного края [2].

Эпицентром проекта стало село Чумой, где на десятилетие обрел свою родину представитель знаменитой фамилии, священнослужитель Васнецов Николай Федорович.

Смысловой ассоциацией проекта послужило величайшее произведение Васнецова Виктора Михайловича «Богатыри».

Витязи русского духа охраняют просторы Отечества. Как завидят врага на горизонте, зажгут костры высокие, а вслед за этим сигналом на другой заставе костер свой разведут, чтобы предупредить о том, что враг наступает.

Так и сегодня, без сражений, враг рода человеческого тьму хитрых ловушек ставит. И попадаются в них слабые духом люди и, как правило, молодые люди. Культура должна взрастить в человеке неразрывную власяницу, чтобы крепостью своею потом человек соблазнам жизни не уступал. И священнический род Васнецовых тому яркий пример [2].

Актуальность данного проекта - в том, что были подняты следующие проблемы:

- подмена истинных ценностей жизни населения, уход от настоящего искусства, отсутствие знаний о жизни семьи Васнецовых в Игринском районе Удмуртской Республики (бывшая Вятская губерния);

- отток молодых людей, интересующихся искусством и умеющих создавать искусство, профессиональных творческих специалистов, умеющих мотивировать и самостоятельно создавать новое искусство.

Цель проекта - популяризация наследия талантливого рода Васнецовых, представители которого служили в храмах Удмуртии, была достигнута через несколько проектных линий. Первая линия - реабилитация детей и взрослых с ограниченными возможностями здоровья средствами культуры и искусства. Вторая - развитие творческих способностей учащихся общеобразователь- ных школ и школ искусств, их преподавателей, мастеров декоративно-прикладного искусства путём вовлечения в круг мероприятий Васнецовской тематики. Третья линия - благоустройство природных уголков в п. Игре и в с. Чумое.

Были проведены арт-терапевтические занятия для людей с ограниченными возможностями. Комплексы традиционных форм работы дополняли инновационные. Например, конференция «на колёсах» под названием «Не зарастёт тропинка к храму».

Мероприятие было организовано в форме «духовных кругов», которые прошли в сёлах, где Васнецов Николай Федорович служил псаломщиком и дьяконом в православных храмах. Были использованы и другие, инновационные формы: инклюзивная арт-терапия, театр-антреприза, создание арт-объектов, арт-зон, пленэр.

Все это стало реальным достижением реализованного проекта. Социальные изменения налицо. И это проявилось не только в качественном изменении пространства с. Чумоя и п. Игры, а, прежде всего, в сознании людей, принимавших прямое или косвенное участие в цикле мероприятий, характеризующих многогранную сущность проекта «Васнецовские символы вечности». Все участники проекта прочувствовали историческую значимость происходящего, прониклись тем, что оказались сопричастными к таким переменам. А общение с интересными людьми (представителями Фонда Васнецовых, землячкой из Австралии, поэтессой и общественным деятелем русской эмиграции в Австралии Людмилой Ларкиной) стало тем историческим свершением, к которому не всякому суждено прикоснуться. Это и есть тот мощный социальный капитал, который удалось реализовать в Игринском районе.

Главный результат проекта - воодушевление местных жителей теми вековечными ценностями, которые, оказывается, находятся рядом и в повседневности будней не всегда оценимы. Произошло духовное прозрение, просветление сознания жителей Игринского района. Это серьезный результат проекта «Васнецовские символы вечности». Такие достижения, несомненно, нужны, поскольку резонанс о проводимых мероприятиях дошёл до республиканского и даже всероссийского уровня. И это стало возможным благодаря использованию ресурсов средств массовой информации, теле- и радиовещания, изданным книгам «Васнецовы на Игринской земле», «Васнецовский альманах» [3]. 


\section{ЛИТЕРАТУРА}

1. 1. [Электронный ресурс]. URL: vasnetsov.foundation (дата обращения 12.03.2020).

2. 2. Васнецовы. Предки и потомки - переплетение судеб: сб. /МБУК «Игринская ЦБС», Игринская центральная районная библиотека им. Кедра Митрея; сост. Н.В. Дубовцева; техн. ред. А.В. Хохрякова. Игра, 2017. 52 с.: фот.

3. 3. Гордеюк В.Г., Скопкарева С.Л. Васнецовы на Игринской земле: научное издание / В.Г. Гордеюк, С.Л. Скопкарева / под ред. Т.И. Зайцевой. Ижевск, 2018. $111 \mathrm{c}$.

4. 4. [Электронный ресурс]. URL: qtrk-vyatka.ru > proect. .. 1812/15004-opolchenie-1812... (дата обращения 22.03.2020).

5. 5. Иднакар: методы историко-культурной реконструкции [Текст]: научно-практ. журн. Васнецовский альманах / МБУК «Игринская ЦБС(». 2018. № 2 (37). 162 с.: ил.

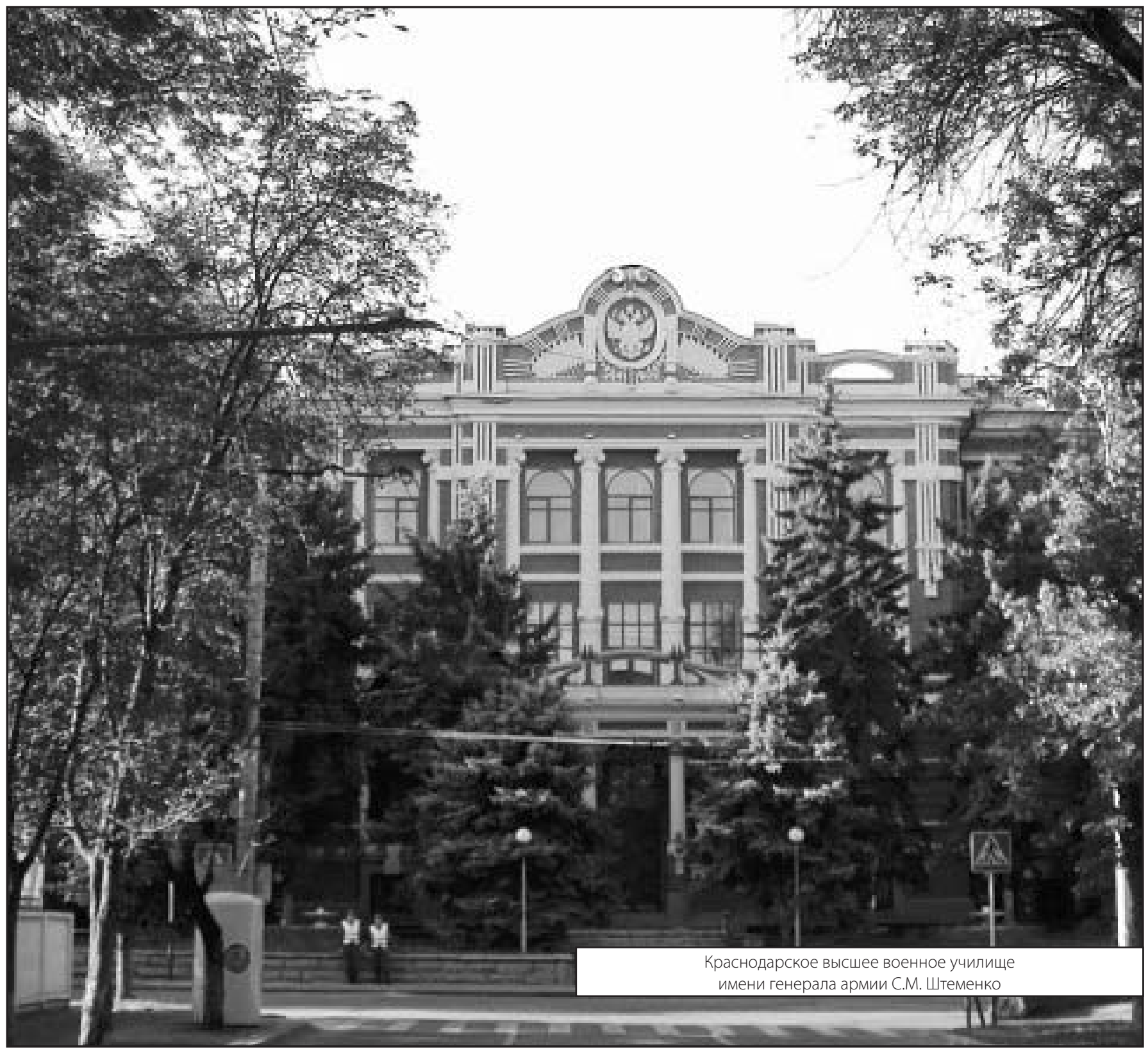

